\title{
STUDY ON ESTIMATION OF SERUM PROSTATE SPECIFIC ANTIGEN LEVEL AND PROSTATE VOLUME WITH TRANS-ABDOMINAL ULTRASONOGRAPHY FINDING IN BENIGN PROSTATE HYPERTROPHY AT TERTIARY CARE HOSPITAL : A CROSS SECTIONAL DESCRIPTIVE STUDY
}

Chandra Prakash Gaire

\author{
Affiliation \\ 1. Lecturer, Department of Biochemistry, Birat Medical College and \\ Teaching Hospital, Nepal
}

\section{ARTICLE INFO}

\section{Received : 21 July, 2021 \\ Accepted : 18 August, 2021}

Published : 04 November 2021

(C) Authors retain copyright and grant the journal right of first publication with the work simultaneously licensed under Creative Commons Attribution License CC - BY 4.0 that allows others to share the work with an acknowledgment of the work's authorship and initial publication in this journal.

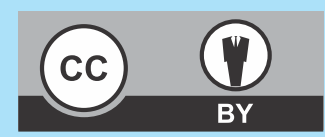

\section{ORA 269}

DOI: https://doi.org/10.3126/bjhs.v6i2.40358

\author{
* Corresponding Author \\ Dr Chandra Prakash Gaire \\ Lecturer \\ Department of Biochemistry \\ Birat Medical College and Teaching Hospital, Nepal \\ Email: gairecpbpkihs01@gmail.com \\ ORCID: https://orcid.org/0000-0001-9120-353x
}

\section{Citation}

Chandra Prakash Gaire, Study on Estimation of Serum Prostate Specific Antigen Level and Prostate Volume with Trans-Abdominal Ultrasonography Finding in Benign Prostate Hypertrophy at Tertiary Care Hospital : A Cross Sectional Descriptive Study. BJHS 2021;6(2)15. 1556-1560.

\section{ABSTRACT}

\section{Introduction}

The periurethral and transition zones of the prostatic gland develop benign prostatic hyperplasia and represent an inevitable phenomenon for the ageing male population. Prostatic specific antigen, is a serine protease, level rises in the blood if the barrier between the lining epithelium and the blood stream is damaged. Benign prostatic hyperplasia, prostatic carcinoma and prostatitis are three common diseases where PSA in the serum is raised. Prostate volume also increases according to age, which can be estimated by trans-abdominal ultrasonography.

\section{Objective}

The aim of the study is to estimate the PSA level in blood and its relationship with prostate volume in benign prostatic hyperplasia patients.

\section{Methodology}

It is a descriptive cross-sectional study which was carried out between a periods of $1^{\text {st }}$ April 2018 to $31^{\text {st }}$ March 2019 at Birat Medical College Teaching Hospital. All the patients diagnosed with benign prostate hyperplasia at the department of urology were included in the study. Blood samples of patients were analyzed for Prostate specific antigen level estimation by chemiluminescence immunosorbent assay. Prostatic volume of the patients was measured by Transabdominal ultrasound technique. Data were entered and analyzed in Microsoft Excel.

\section{Result}

A total of 68 patients were diagnosed with benign prostate hyperplasia. The mean age of the patients was $61.8 \pm 12.3$ years. The maximum number 23 of patients with BPH was there in age group 51-60. The maximum no of patients 38 were having their PSA level between the range of 4.0-10.0 $\mathrm{ng} / \mathrm{ml}$. The maximum no of patients 28 was having Prostate volume in the range of $40-60 \mathrm{gm}$. The maximum number of patients 31 was having diabetes mellitus as a co-morbid association. The maximum mean PSA level and prostate volume in the patients were observed in age group $>80$ years, which was $20.1 \pm 8.6 \mathrm{ng} / \mathrm{ml}$ and $>80$ gm respectively.

\section{Conclusion}

The prostate specific antigen level and prostate volume both increase in advance age group of patients suffering with benign prostate hyperplasia.

\section{KEYWORDS}

Hyperplasia, Prostate, Ultrasonography 


\section{INTRODUCTION}

Benign prostatic hyperplasia arises in the periurethral and transition zones of the prostatic gland and represents an inevitable phenomenon for the ageing male population. Prostate is fibro-musculo-glandular organ which is located around the neck of the urinary bladder. Prostatic enlargement that may due to any cause may give rise to bladder outlet obstruction. ${ }^{1}$ Benign prostatic hyperplasia $(\mathrm{BPH})$ is a progressive condition characterized by prostate enlargement accompanied by lower urinary tract symptoms. An estimated $75 \%$ of men $>50$ years of age have symptoms arising from benign prostatic hyperplasia, and $20-30 \%$ of men reaching 80 years of age require surgical intervention for the management of $\mathrm{BPH} .{ }^{2}$ Prostate is a male specific organ and the rate of clinical symptoms due to obstruction of the bladder neck goes up as the age rises due to increase in prostatic volume. ${ }^{3} \mathrm{BPH}$ affects both glandular epithelium and connective tissue stroma to variable degrees in which adenosis, epitheliosis and stromal proliferation are seen in differing proportions. ${ }^{4}$

A serine protease enzyme, i.e. PSA having the molecular weight $33 \mathrm{kDa}$, produced by the prostate epithelium and periurethral glands in male.PSA is normally formed as a proenzyme, secreted primarily by the secretory acinar cells that line the prostate and are secreted into the lumen. PSA is the enzyme that is responsible for liquefaction of semen within a few minutes after it has clotted. ${ }^{5}$ Serum PSA elevations occur as a result of disruption of normal prostatic architecture that allows PSA to diffuse into prostatic tissue and gain access to the circulation. PSA levels in the blood go up if the barrier between the lining epithelium and the blood stream is damaged. PSA is a prostatic specific but it does not specify the type of the disease. ${ }^{6}$ This can occur in the setting of prostate disease and prostate manipulation. Benign prostatic hyperplasia, prostatic carcinoma and prostatitis are three common diseases where PSA in the serum is raised.

During the course of different prostatic diseases including benign prostatic hyperplasia, prostate volume (PV) varies widely throughout individual's lifetime. The development of highly specialized ultrasound equipment has allowed the application of this imaging technique in the diagnosis, treatment and follows up of prostatic disease, particularly $\mathrm{BPH}$. Transabdominal ultrasound measurement of prostate volume is consistent and correlated to transrectal prostate volume when the bladder volume is less than $400 \mathrm{ml}$. In normal person, the serum concentration of PSA is proportional to the volume of prostatic epithelium, but the release of PSA from $\mathrm{BPH}$ is three fold that from the normal prostate. Therefore, the rationale of present piece of work aimed to estimate serum PSA level and its relationship with volume of prostate, estimated by trans-abdominal ultrasonography in BPH patients.

\section{METHODOLOGY}

This is a descriptive cross-sectional study which was carried out between a periods of $1^{\text {st }}$ April 2018 to $31^{\text {st }}$ March 2019 at
Birat Medical College Teaching Hospital after getting the approval from the Institutional Review Committee. All the patients, who presented to Urology department and diagnosed with BPH by serum PSA level and transabdominal ultrasonography in the department of Biochemistry Radiology respectively, were enrolled for the study. Whole sampling was done. All the participants had signed the informed consent for the study. The sample size was calculated, using formula $\mathrm{Z}^{2} \mathrm{Pq} / \mathrm{d}^{2}\left(\mathrm{Z}=1.96, \mathrm{P}=0.21^{7}\right.$, $q=0.79, d=0.1$ ) at $95 \%$ confidence interval with $10 \%$ error, as 64 . We enrolled all the 68 samples for the study.

\section{Inclusion criteria}

1. Participants who provided informed consent

2. Who were diagnosed as BPH by trained urologist

3. Age $\geq 25$ years

\section{Exclusion criteria}

1. Participants with prostate cancer

2. Participants with chronic kidney or liver disease / because chronic liver and Kidney disease may influence prostate disease.

Blood sample of the patients was collected for the estimation of prostate specific antigen level. $5 \mathrm{ml}$ of venous blood was drawn and collected in the vial. Serum part was separated by centrifuging vial at room temperature. PSA was estimated by chemi luminescence immunosorbent assay (CLIA), a solid phase two-site immunoassay. Transabdominal ultrasound was used to measure prostatic volume at Radiology Department. Patients with minimal bladder volume of 100 to $200 \mathrm{ml}$ were subjected to USG for near correct estimation of prostate volume by USG. ${ }^{8}$

Data were entered and calculations were done in Microsoft Excel, point estimate at $95 \%$ Confidence Interval was calculated along with frequency and proportion for binary data.

\section{RESULTS}

A total of 68 patients were enrolled for this study. The mean age of the patients was $61.8 \pm 12.3$ years. Age of the patients varied between ranges of 42 to 87 years. The number of patients diagnosed with $\mathrm{BPH}$ in different age groups is mentioned in Table 1 . The maximum number (23) of patients with $\mathrm{BPH}$ was there in age group 51-60. The estimated PSA level was categorized in four groups and the maximum no of patients 38 were having their PSA level between the range of $4.0-10.0 \mathrm{ng} / \mathrm{ml}$. Few patients 5 were having their PSA level below than $4.0 \mathrm{ng} / \mathrm{ml}$ as shown in Table 2.

Table 1: Distribution of patients based on specified age groups and sex $(n=154)$.

\begin{tabular}{|c|c|}
\hline Age group & Frequency (n) \\
\hline $40-50$ & $8(11.7 \%)$ \\
\hline $51-60$ & $23(33.8 \%)$ \\
\hline $61-70$ & $19(27.9 \%)$ \\
\hline $71-80$ & $13(19.1 \%)$ \\
\hline$>80$ & $5(7.3 \%)$ \\
\hline
\end{tabular}




Table 2: PSA level in all age group of patients
\begin{tabular}{|c|c|}
\hline PSA (ng/ml) & Frequency (n) \\
\hline$<4.0$ & $5(7.3 \%)$ \\
\hline $4.0-10.0$ & $38(55.8 \%)$ \\
\hline $10.1-20.0$ & $18(26.4 \%)$ \\
\hline$>20.0$ & $7(10.2 \%)$ \\
\hline
\end{tabular}

All patients were diagnosed for $\mathrm{BPH}$ by subjecting them to transabdominal ultrasound. The volume of prostate is shown in Table 3 . The maximum no of patients 28 was having Prostate volume in the range of 40-60 gm as shown in Table 3. All the patients with BPH were evaluated for their co-morbid conditions and it was noted that maximum patients 31 were having diabetes mellitus as shown in Table 4. The minimum number of patients 3 was having COPD as associated condition.

Table 3: Prostrate volume wise distribution of patients

\begin{tabular}{|c|c|}
\hline PSA (ng/ml) & Frequency (n) \\
\hline$<4.0$ & $5(7.3 \%)$ \\
\hline $4.0-10.0$ & $38(55.8 \%)$ \\
\hline $10.1-20.0$ & $18(26.4 \%)$ \\
\hline$>20.0$ & $7(10.2 \%)$ \\
\hline
\end{tabular}

Table 4: Co-morbidities of patients

\begin{tabular}{|l|l|}
\hline Associated Conditions & Frequency (n) \\
\hline Diabetes Mellitus & $31(45.5 \%)$ \\
\hline Hypertension & $20(29.4 \%)$ \\
\hline Kidney failure & $9(13.2 \%)$ \\
\hline Alcoholics & $5(7.3 \%)$ \\
\hline COPD & $3(4.4 \%)$ \\
\hline
\end{tabular}

The elevated mean value of PSA level of the patients in the age group of $40-50$ years showed $8.4 \pm 3.1 \mathrm{ng} / \mathrm{ml}$, whereas the elevated mean PSA level of the patients in the 51-60 year age group showed $12.6 \pm 4.8 \mathrm{ng} / \mathrm{ml}$. The age group of $61-70$ \& $71-80$ years had $15.3 \pm 7.7 \mathrm{ng} / \mathrm{ml}$ and $17.7 \pm 8.6 \mathrm{ng} / \mathrm{ml}$ as the elevated mean PSA level respectively. The mean PSA level of $>80$ years of patients was $20.1 \pm 8.6 \mathrm{ng} / \mathrm{ml}$ as shown in Figure 1. Similarly, the mean prostate volume of patients of $>80$ years was found $>80 \mathrm{gm}$, which was higher than other age groups of patients as shown in figure 2 .

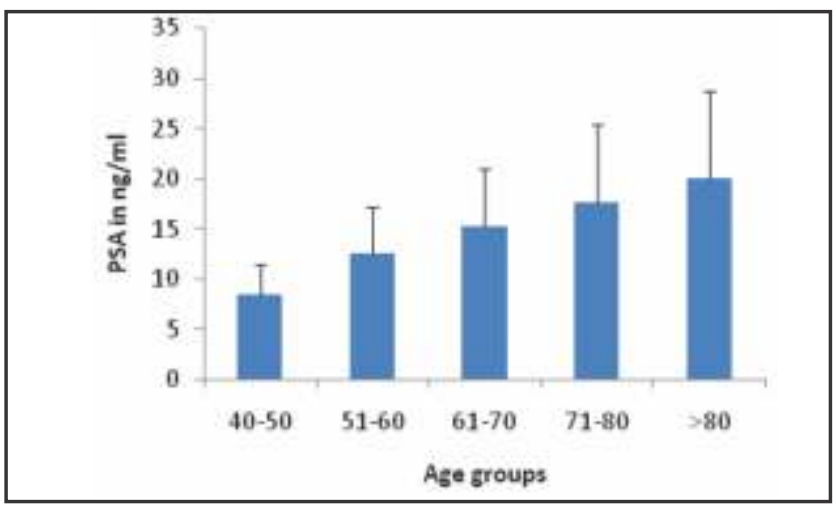

Figure 1: The elevated mean PSA level in different age group of patients

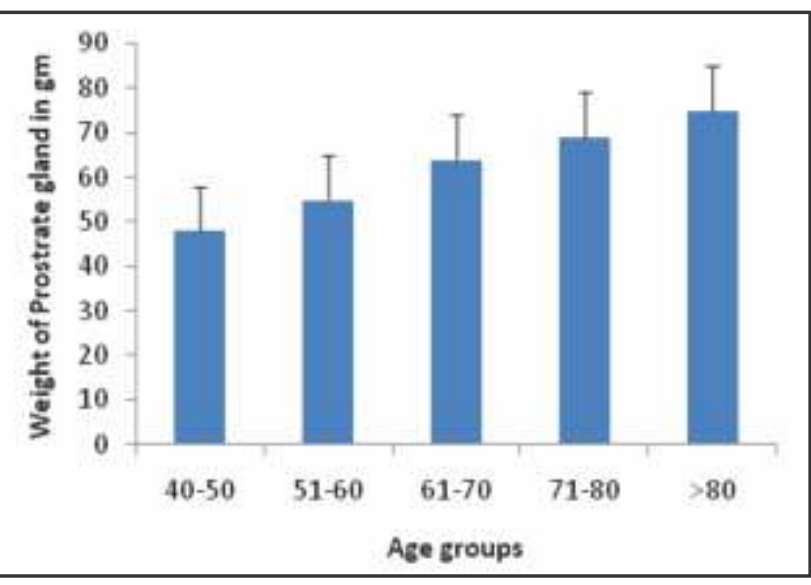

Figure 2: The mean weight of Prostate gland in different age group of patients

Table 3: Prostrate volume wise distribution of patients
\begin{tabular}{|l|c|c|}
\hline Variables & Pearson's correlation & $\begin{array}{c}\text { Significance } \\
\text { (p-value) }\end{array}$ \\
\hline PSA Vs Weight & 0.763 & $<0.001^{*}$ \\
\hline PSA Vs age & 0.802 & $<0.001^{*}$ \\
\hline Weight Vs age & 0.838 & $<0.001^{*}$ \\
\hline
\end{tabular}

*Significance at 0.05 level

\section{DISCUSSION}

Benign prostate hypertrophy is most common benign tumour in men, and its incidence is age related. The maximum cases of BPH were recorded in age group 51-60 in this study. One of the study demonstrated that the percentage of male with enlargement of prostate increases from $20 \%$ at 40 years of age to $70 \%$ by age 60 and $90 \%$ by eighth decade of life. ${ }^{9}$ In this study the PSA level showed significant correlation with both patient age and weight of the prostate gland $(P<0.05)$, Similarly the weight of the gland was also significantly correlated with the age of the patient $(P<0.05)$ In the present study, age group of the patient varied from 42 to 87 years with the mean age $61.8 \pm 12.3$ years, where as in the study done by Hirachand et al, ${ }^{10}$ age group of the patient was $46-88$ years with the mean age of 68 years which is similar to the study done by Banerjee $B$, Lakhey $\mathrm{M}$, RajasundaramRwith the mean age 65.55, 67.61, 69.7 years. $^{11-13}$

Prostatic Specific Antigen is produced only by the lining cells of prostatic acini and prostatic tissue. Since it is produced only by prostate, it is considered as the serum marker for Prostatic carcinoma. Unfortunately PSA is specific for prostate but not for the prostatic disease. Its concentration was also found to increase in BPH, PIN and Prostatitis. Epithelial cells of all types of prostatic tissue, benign and malignant produce PSA. Prostatic lesions are more common in the elderly age group, BPH more common than carcinoma of prostate. Prostate specific antigen level is raised in both the neoplastic and non-neoplastic lesions of prostate. The peri urethral glands produce extra prostatic PSA, which is measurable in urine but cannot be detected in serum in women and in men. The liquification of the ejaculate, done by PSA, increases the motility of sperms ${ }^{14}$ PSA level has got prognostic value too in diagnosed patients. PSA is accurate 
and precise noninvasive biomarker and its diagnostic significance is well documented. In this study, 38 patients were having their PSA range between $4-10 \mathrm{ng} / \mathrm{ml}, 18$ patients with PSA $10.1-20 \mathrm{ng} / \mathrm{ml}, 7$ patients with PSA >20 $\mathrm{ng} / \mathrm{ml}$ and 5 patients with PSA $<4 \mathrm{ng} / \mathrm{ml}$. In the study done by Kamaleshwaran et al, ${ }^{15} 94.87 \%$ of the total BPH patient have a serum PSA level less than $10 \mathrm{ng} / \mathrm{ml}$, whereas in the another study done by Hirachand et al, $73.43 \%$ had a serum PSA level less than $7 \mathrm{ng} / \mathrm{ml}$. All patients were diagnosed for $\mathrm{BPH}$ by subjecting them to transabdominal ultrasound. The maximum no of patients 28 was having Prostate volume in the range of $40-60 \mathrm{gm}$ in the present study. In a study, it was observed that $46.7 \%$ patients had prostatic volume of $40-59$ gm, $60 \%$ had $60-79 \mathrm{gm}$ and $13.3 \%$ had $>80 \mathrm{gm} .{ }^{16}$ The gold standard triad for diagnosing prostate disease comprised of Prostate specific antigen (PSA) level estimation in blood and Transrectal ultrasonography.

We have analyzed the level of PSA among the patients of different age group. The age group of $61-70 \& 71-80$ years had $15.3 \pm 7.7 \mathrm{ng} / \mathrm{ml}$ and $17.7 \pm 8.6 \mathrm{ng} / \mathrm{ml}$ as the elevated mean PSA level respectively. The mean PSA level of $>80$ years of patients was $20.1 \pm 8.6 \mathrm{ng} / \mathrm{ml}$. The mean PSA value of $49.8 \pm 6.0 \mathrm{ng} / \mathrm{ml}$ has been reported in one study, which was carried out in Chinese men suffering with prostate cancer. ${ }^{17}$ Similarly, in another study carried in eastern Nepal, it was observed that the highest PSA value was upto $34.5 \mathrm{ng} / \mathrm{ml}$, observed in age group of $81-88$ years. ${ }^{18}$ The mean PSA value of patients of age groups (30-39), (40-49), (50-59), (60-69) and $>70$ has been reported as $0.86 \pm 0.81$, $1.21 \pm 0.6,1.59 \pm 0.67,2.12 \pm 0.84$ and $2.76 \pm 0.91 \mathrm{ng} / \mathrm{ml}$ respectively in prostate disease-free Chinese men population. ${ }^{17}$ Similarly, the mean PSA value in Spanish workers without prostate problems in the age group of under 40 years, (4049), (50-59) and (60-64) has been reported as $0.67 \pm 0.49$, $0.77 \pm 0.66,1.11 \pm 1.22$ and $1.57 \pm 1.72 \mathrm{ng} / \mathrm{ml}$ respectively. ${ }^{19}$

The age-specific PSA reference range reflects the association between PSA and age. As men's age increases, the value of their serum PSA also increases. This is because of the enlarged prostate and increased leakage of the prostatic epithelium. It seems to be due to the subclinical inflammation or microscopic foci of cellular atypia. In this present study, we observed that the higher age group had

\section{REFERENCES}

1. Vani BR, Kumar D, Sharath BN, Murthy VS, Geethamala K. A comprehensive study of prostate pathology in correlation with prostate-specific antigen levels: An Indian study. Clinical Cancer Investigation Journal. 2015 Sep 1;4(5):617.DOI: 10.4103/22780513.164722.

2. Briganti A, Capitanio U, Suardi N, Gallina A, Salonia A, Bianchi M, Tutolo M, Di Girolamo V, Guazzoni G, Rigatti P, Montorsi F. Benign prostatic hyperplasia and its aetiologies. European Urology Supplements. 2009 Dec 1;8(13):865-71. DOI: https://doi.org/ 10.1016/j.eursup.2009.11.002

3. Mullan RJ, Bergstralh EJ, Farmer SA, Jacobson DJ, Hebbring SJ, Cunningham JM, Thibodeau SN, Lieber MM, Jacobsen SJ, Roberts RO. Growth factor, cytokine, and vitamin D receptor polymorphisms and risk of benign prostatic hyperplasia in a community-based cohort of men. Urology. 2006 Feb 1;67(2):300-5. DOI: https://doi.org/10.1016/j.urology.2005.08.061. more level of elevated mean PSA than lower age group. Similarly, prostate volume was also found to be higher in higher age group of patients.

\section{CONCLUSION}

The present study revealed that mean PSA and prostate volume increased with advance age in $\mathrm{BPH}$ patients. BPH was more associated with patients suffering with Diabetes mellitus.

\section{RECOMMENDATION}

Prostate specific antigen level estimation in blood and measurement of prostatic volume by trans-abdominal ultrasonography are really very helpful in diagnosing the various patho-physiology related with prostate gland. Timely diagnosis followed with accurate treatment yields with better prognosis and disease management. PSA has been recommended test in guidelines of the American cancer society since 1993 for annual check-up of men aged 50 years or above and has resulted in early diagnosis and treatment. Hence the estimation of PSA level in serum can be used as a diagnostic tool for screening prostate disease. So, a well regulated awareness program through NGOs or Health department may be initiated so that various diseases related with prostate may be reduced among males.

\section{LIMITATIONS OF THE STUDY}

Low sample size.

\section{ACKNOWLEDGEMENTS}

I would like to express my deep and sincere thanks to patients suffering with BPH and staffs of Urology Clinic, Radiology, Clinical laboratory, Birat Medical College Teaching Hospital for their help and support to conduct the study on BPH patients.

\section{CONFLICT OF INTEREST \\ None}

\section{FINANCIAL DISCLOSURE}

None

4. Alawad AA, Younis FH, Eltoum AM, Abdelgani SA. Serum prostatespecific antigen as a predictor of prostate volume in Sudanese patients with benign prostatic hyperplasia. Age (year). 2014;51(61): 62-72. DOI: 10.14419/ijm.v2i1.2494.

5. Oesterling JE, Jacobsen SJ, Chute CG, Guess HA, Girman CJ, Panser LA, Lieber MM. Serum prostate-specific antigen in a communitybased population of healthy men: establishment of age-specific reference ranges. Jama. 1993 Aug 18;270(7):860-4. DOI:10.1001/ jama.1993.03510070082041

6. Fitzpatrick JM. PSA measurement in the treatment of BPH. BJU Int. 2004;93Suppl 1:2-4. DOI: 10.1111/j.1464-410X.2003.04632.x

7. Lilja $H$. Structure and function of prostatic-and seminal vesiclesecreted proteins involved in the gelation and liquefaction of human semen. Scandinavian Journal of Clinical and Laboratory Investigation. 1988 Jan 1;48(sup191):13-20. DOI: https://doi.org/ $10.1080 / 00365518809168290$ 
8. Bapat SS, Purnapatre SS, Pai KV, Yadav P, Padhye A, Bodhe YG. Does estimation of prostate volume by abdominal ultrasonography vary with bladder volume: A prospective study with transrectal ultrasonography as a reference. Indian Journal of Urology. 2006 Oct 1;22(4):322. DOI: 10.4103/0970-1591.29114

9. Josephine A. Clinicopathological study of prostatic biopsies. Journal of clinical and diagnostic research: JCDR. 2014 Sep;8(9):FC04.DOI: 10.7860/JCDR/2014/8591.4843.

10. Hirachand S, Dangol UM, Pradhanang S, Acharya S. Study of prostatic pathology and its correlation with prostate specific antigen level. Journal of Pathology of Nepal. 2017 Mar 30;7(1):1074-7. DOI: https://doi.org/10.3126/jpn.v7i1.16911

11. Banerjee B, Iqbal BM, Kumar H, Kambale T, Bavikar R. Correlation between prostate specific antigen levels and various prostatic pathologies. Journal of Medical Society. 2016 Sep 1;30(3):172. DOI: 10.4103/0972-4958.191184.

12. Lakhey $M$, Ghimire R, Shrestha R, Bhatta AD. Correlation of serum free prostate-specific antigen level with histological findings in patients with prostatic disease. Kathmandu University Medical Journal. 2010;8(2):158-63. DOI: https://doi.org/10.3126/ kumj. v8i2.3550

13. Rajasundaram R, Gunendran T, George N. Surgical castration for androgen-deprivation therapy of prostate cancer-relevance in current practice. Journal of Clinical Urology. 2013 Mar;6(2):89-93. DOI: https://doi.org/10.1177/1875974212465549.
14. Lilja H. A kallikrein like serum protease in prostatic fluid cleaves the predominant seminal vesicle protein. J Clin Invest 1985;76:1899903. DOI: https://doi.org/10.1172/JCl112185

15. Kamaleshwaran KK, Mittal BR, Harisankar CN, Bhattacharya A, Singh SK, Mandal AK. Predictive value of serum prostate specific antigen in detecting bone metastasis in prostate cancer patients using bone scintigraphy. Indian journal of nuclear medicine: IJNM: the official journal of the Society of Nuclear Medicine, India. 2012 Apr;27(2):81. DOI: 10.4103/0972-3919.110683

16. Bharti SV. Correlation between serum prostatic specific antigen and prostatic volume in benign prostatic hyperplasia. Journal of Nepalgunj Medical College. 2017 Jul 31;15(1):9-15. DOI: https:// doi.org/10.3126/jngmc.v15i1.23531

17. Zhang $P$, Wang ZM, Zhong $T$, Zhao LH. Analysis of the results of percent free prostate specific antigen detection among the men without prostate diseases in Xi'an. Journal of southern Medical University. 2008 Feb 1;28(2):269-71. PMID: 18250060.

18. Shreewastav RK, Gaire CP, Ghimire A, Shah PK, Singh AG. Evaluation of prostate specific antigen level in different age group of Patients in Eastern part of Nepal. Journal of Nobel Medical College. 2016 Sep 23;5(1):14-9. DOI: https://doi.org/10.3126/jonmc.v5i1.15748

19. Gelpi-Méndez JA, Gómez-Fernández E, Martín-Barallat J, CortésArcas MV, Monsonis-Artero JV, Calvo-Mora A. Reference values of prostate specific antigen (PSA) in 63926 workers without prostatic symptoms who participated in prostate screening cancer developed by the Ibermutuamur Prevention Society in 2006. Actas Urológicas Españolas (English Edition). 2010 Jan 1;34(8):669-76. DOI: https:// doi.org/10.1016/S2173-5786(10)70168-2. 